\title{
A case of a depressive patient with alcohol and nicotine dependence successfully treated with sertraline
}

\author{
Wakako Umene-Nakano, M.D., Ph.D., Reiji Yoshimura, M.D., Ph.D., \\ Asuka Katsuki, M.D. and Jun Nakamura, M.D., Ph.D. \\ Department of Psychiatry, School of Medicine, University of \\ Occupational and Environmental Health, Japan
}

\begin{abstract}
Multiple studies have reported that tobacco smoking, alcohol use, and depression are interrelated. Here we report a case of a 54-year old male depressive patient with comorbid alcohol and nicotine dependence who was successfully treated with sertraline. After treatment with sertraline, the patient's plasma levels of MHPG and HVA were increased, but his serum BDNF level was. Sertraline exhibits more potent efficacy than other SSRIs in inhibiting dopamine reuptake. This unique effect of sertraline on catecholamine systems contributed to the successful outcome in this case.
\end{abstract}

\section{Keywords: depression, alcohol dependence, nicotine dependence, sertraline, smoking cessation}

Received May 13, 2011 / Accepted June 29, 2011 / Published July 21, 2011

\section{INTRODUCTION}

Multiple studies have demonstrated that tobacco smoking, alcohol use, and depression are interrelated. Patients with mood disorders have higher rates of smoking and greater difficulty quitting smoking [1]. Smokers are more likely to consume alcohol, and those with alcohol problems experience greater difficulty quitting smoking [2]. Both smoking and alcohol abuse are associated with depression, and there are certain psychobiological mechanisms of co-morbidity among the three factors [3]. Here we present a case of a depressive patient with alcohol and nicotine dependence successfully treated with sertraline. The authors also longitudinally followed up the plasma levels of homovanillic acid (HVA), a major metabolite of dopamine, and 3-methoxy4-hydroxyphenylglycol (MHPG), a major metabolite of noradrenaline and brain-derived neurotrophic factor (BDNF), in this case.

\section{CASE PRESENTATION}

Mr. A, a 54-year-old man, met the DSM-IV criteria for major depression, alcohol dependence, and nicotine dependence. He had developed a major depressive disorder and alcohol dependence because of stress from work 1 year prior to coming to our program for consultation. His depressive symptoms consisted of depressed mood, irritability, insomnia, loss of appetite, feelings of guilt, markedly diminished interest and pleasure in almost all activities, difficulty concentrating, and suicidal thoughts. His score on the Hamilton Rating Scale for Depression was 20. He had been experiencing nicotine dependence for many years and smoked 30 cigarettes per day. His score on the Fagerstrom Test for nicotine dependence was 10 and therefore consistent with a physical syndrome of nicotine dependence. His score on the alcohol use disorders identification test was 18 . He was admitted to our

Corresponding Author: Wakako Umene-Nakano, M.D., Ph.D., Department of Psychiatry, School of Medicine, University of Occupational and Environmental Health, 1-1 Iseigaoka, Yahatanishi-ku, Kitakyushu, Fukuoka 8078555, Japan

Tel.: +81936917253 Fax: +81936924894 E-mail: wakako-u@med.uoeh-u.ac.jp 
psychiatric ward. He had never received any psychiatric treatment or medication before this admission. He was treated with sertraline $25 \mathrm{mg} /$ day for a few weeks, and with nicotine patches, at $30 \mathrm{mg} /$ day, for one week. He also received cognitive behavior therapy for alcohol dependency. His depressive symptoms improved after 10 weeks. His score on the Hamilton Rating Scale for Depression fell to 7 when his sertraline dose was increased to $100 \mathrm{mg}$ / day, and he succeeded in quitting smoking and drinking after 10 weeks of treatment with sertraline. His plasma levels of HVA and MHPG were $5.7 \mathrm{ng} / \mathrm{ml}$ and 3.1 $\mathrm{ng} / \mathrm{ml}$ before treatment, $5.6 \mathrm{ng} / \mathrm{ml}$ and $5.4 \mathrm{ng} / \mathrm{ml} 2$ weeks after treatment, $5.0 \mathrm{ng} / \mathrm{ml}$ and $7.9 \mathrm{mg} / \mathrm{ml} 4$ weeks after treatment, and $7.8 \mathrm{ng} / \mathrm{ml}$ and $9.9 \mathrm{ng} / \mathrm{ml}$ 10 weeks after treatment. His serum levels of BDNF before and at 2, 4, and 10 weeks after treatment were $1.4 \mathrm{ng} / \mathrm{ml}, 1.8 \mathrm{ng} / \mathrm{ml}, 2.2 \mathrm{ng} / \mathrm{ml}$, and $1.8 \mathrm{ng} / \mathrm{ml}$, respectively. We measured serum levels of MHPG and HVA by high-performance liquid chromatography, and we measured serum BDNF levels by ELISA. The CV (intra- and inter-assay) of MHPG, HVA, and BDNF were all below $10 \%$.

\section{DISCUSSION}

A number of behavioral and pharmacological treatments, such as nicotine replacement therapy and administration of varenicline and antidepressants, have been shown to aid smoking cessation $[4,5]$. Among antidepressants, bupropion and nortriptyline have been proposed for the treatment of nicotine dependence [6]. Bupropion inhibits neuronal noradrenaline (NA) and dopamine (DA) reuptake and is thought to reduce tobacco withdrawal symptoms by enhancing central DA concentrations. Clinical studies showed that bupropion is effective in both initial smoking cessation and relapse prevention. Among SSRIs, sertraline is only one of several antidepressant medications that have been tested as treatments for nicotine dependence. This line of research was spurred by observations of the deleterious influence of depressed mood [7, 8] and major depressive disorder [9] on cessation. Sertraline inhibited dopamine transporter more successfully than did other SSRIs [10].

We have reported that sertraline plays an important role in clinical efficacy in treating depressive patients [11]. In contrast, Covey et al [12] reported unsuccessful results in using sertraline for smoking cessation. Among patients who develop problem drinking early in life, have a strong family history of alcoholism, and frequently exhibit impulsive behaviors, fluoxetine worsens drinking outcomes [13]. In contrast, sertraline improves drinking outcomes among patients who develop problem drinking later in life and do not have a family history of impulsive behavior [14]. In the present case, the plasma MHPG and HVA levels increased, and the serum BDNF level did not change after treatment with sertraline. We have previously reported that serum BDNF levels did not increase after treatment with varenicline for 8 weeks in smokers [15]. Taking these findings into account, although pharmacotherapeutic approaches to comorbidity of depression and alcohol and nicotine dependence have not been established, sertraline is a candidate drug for the treatment of such patients via enhancement of the catecholaminergic system without affecting BDNF.

\section{REFERENCES}

[1] Laje RP, Berman JA, Glassman AH. Depression and nicotine: preclinical and clinical evidence for common mechanisms. Curr Psychiatry Rep 2001; 3: 470-4.

[2] Patten CA, Martin JE, Calfas KJ, Lento J, Wolter TD. Behavioral treatment for smokers with a history of alcoholism: predictors of successful outcome. J Consult Clin Psychol 2001; 69: 796-801.

[3] Saatcioglu O, Celikel FC, Cakmak D. Depression and anxiety in alcohol dependent inpatients who smoke. Isr J Psychiatry Relat Sci 2008; 45: 33-8.

[4] Schneider NG, Cortner C, Gould JL, Koury MA, Olmstead RE. Comparison of craving and withdrawal among four combination nicotine treatments. Hum Psychopharmacol 2008; 23: 513-7.

[5] Gonzales D, Rennard SI, Nides M, Oncken, C., Azoulay, S., Billing, C. B. Varenicline, an alpha4beta2 nicotinic acetylcholine receptor partial agonist, vs sustained-release bupropion and placebo for smoking cessation: a randomized controlled trial. JAMA 2006; 296: 47-55.

[6] George TP, O'Malley SS. Current pharmacological treatments for nicotine dependence. Trends Pharmacol Sci 2004; 25: 42-8.

[7] Anda RF, Williamson DF, Escobedo LG, Mast EE, Giovino GA, Remington PL. Depression and the dynamics of smoking. A national 
perspective. JAMA 1990; 264: 1541-5.

[8] Covey LS, Glassman AH, Stetner F. Depression and depressive symptoms in smoking cessation. Compr Psychiatry 1990; 31: 350-4.

[9] Glassman AH, Stetner F, Walsh BT, , Raizman, P. S., Fleiss, J. L., Cooper, T. B. Heavy smokers, smoking cessation, and clonidine. Results of a double-blind, randomized trial. JAMA 1988; 259: 2863-6.

[10] Bolden-Watson C, Richelson E. Blockade by newly-developed antidepressants of biogenic amine uptake into rat brain synaptosomes. Life Sci 1993; 52: 1023-9.

[11] Umene-Nakano W, Yoshimura R, Ueda N, Suzuki, A., Ikenouchi-Sugita, A., Hori, H. Predictive factors for responding to sertraline treatment: views from plasma catecholamine metabolites and serotonin transporter polymorphism. J Psychopharmacol 2010; 24: 1764-71.

[12] Covey LS, Glassman AH, Stetner F, Rivelli S, Stage K. A randomized trial of sertraline as a cessation aid for smokers with a history of major depression. Am J Psychiatry 2002; 159: 1731-7.

[13] Kranzler HR, Burleson JA, Brown J, Babor TF. Fluoxetine treatment seems to reduce the beneficial effects of cognitive-behavioral therapy in type B alcoholics. Alcohol Clin Exp Res 1996; 20: 1534-41.

[14] Pettinati HM, Volpicelli JR, Kranzler HR, Luck G, Rukstalis MR, Cnaan A. Sertraline treatment for alcohol dependence: interactive effects of medication and alcoholic subtype. Alcohol Clin Exp Res 2000; 24: 1041-9.

[15] Umene-Nakano W, Yoshimura R, Yoshii C , Hoshuyama T, Hayashi K, Hori H, Katsuki A, Ikenouchi-Sugita A, Nakamura J. Varenicline does not increase serum BDNF levels in patients with nicotine dependence. Hum Psychopharmacol 2010; 25: 276-9. 